\title{
The Effects of a Single Freeze-Thaw Cycle on Concentrations of Nutritional, Noncommunicable Disease, and Inflammatory Biomarkers in Serum Samples
}

Ransi Ann Abraham Garima Rana ${ }^{1}$ Praween K. Agrawal ${ }^{2}$ Robert Johnston ${ }^{2}$ Avina Sarna ${ }^{3}$ Sowmya Ramesh ${ }^{3}$ Rajib Acharya ${ }^{3} \quad$ Nizamuddin Khan $^{3} \quad$ Akash Porwal $^{3} \quad$ Sucheta Banerjee Kurundkar ${ }^{4}$ Arvind Pandey ${ }^{5}$ Raghu Pullakhandam ${ }^{6} \quad$ Krishnapillai Madhavan Nair ${ }^{6} \quad$ Geeta Trilok Kumar ${ }^{7}$ HPS Sachdev ${ }^{8} \quad$ Umesh Kapil $^{9} \quad$ Sila Deb ${ }^{10} \quad$ Arjan de Wagt $^{2} \quad$ Ajay Khera ${ }^{10} \quad$ Lakshmy Ramakrishnan $^{1}$

\author{
${ }^{1}$ Department of Cardiac Biochemistry, All India Institute of Medical \\ Sciences, Delhi, India \\ 2UNICEF, Delhi, India \\ ${ }^{3}$ Population Council, Delhi, India \\ ${ }^{4}$ Clinical Development Services Agency, Translational Health \\ Science \& Technology Institute, Faridabad, Haryana \\ ${ }^{5}$ National Institute of Medical Statistics, Indian Council of Medical \\ Research, Delhi, India \\ ${ }^{6}$ National Institute of Nutrition, Hyderabad, Telangana, India \\ ${ }^{7}$ Institute of Home economics, Delhi, India \\ 8 Paediatrics and Clinical Epidemiology, B-16 Qutab Institutional \\ Area, New Delhi, India \\ ${ }^{9}$ Department of Human Nutrition, All India Institute of Medical \\ Sciences, Delhi, India \\ 10 Ministry of Health and Family Welfare, Delhi, India
}

\author{
Address for correspondence Lakshmy Ramakrishnan, PhD \\ Department of Cardiac Biochemistry, All India Institute of \\ Medical Sciences, Ansari Nagar, New Delhi 110029, India \\ (e-mail: lakshmy_ram@yahoo.com).
}

J Lab Physicians 2021;13:6-13.

\author{
Abstract \\ Keywords \\ - nutrition and \\ noncommunicable \\ diseases biomarkers \\ - serum sample \\ - bioanalytes \\ - freeze-thaw \\ - stability \\ - analysis \\ - storage
}

Background The stability of biological samples is vital for reliable measurements of biomarkers in large-scale survey settings, which may be affected by freeze-thaw procedures. We examined the effect of a single freeze-thaw cycle on 13 nutritional, noncommunicable diseases (NCD), and inflammatory bioanalytes in serum samples. Method Blood samples were collected from 70 subjects centrifuged after 30 minutes and aliquoted immediately. After a baseline analysis of the analytes, the samples were stored at $-70^{\circ} \mathrm{C}$ for 1 month and reanalyzed for all the parameters. Mean percentage differences between baseline (fresh blood) and freeze-thaw concentrations were calculated using paired sample $t$-tests and evaluated according to total allowable error (TEa) limits (desirable bias).

Results Freeze-thaw concentrations differed significantly $(p<0.05)$ from baseline concentrations for soluble transferrin receptor (sTfR) $(-5.49 \%)$, vitamin D $(-12.51 \%)$, vitamin B12 (- 3.74\%), plasma glucose (1.93\%), C-reactive protein (CRP) (3.45\%), published online May 24, 2021
DOI https://doi.org/

10.1055s-0041-1726575 ISSN 0974-2727.
(C)2021. The Indian Association of Laboratory Physicians.

This is an open access article published by Thieme under the terms of the Creative Commons Attribution-NonDerivative-NonCommercial-License, permitting copying and reproduction so long as the original work is given appropriate credit. Contents may not be used for commercial purposes, or adapted, remixed, transformed or built upon. (https://creativecommons.org/licenses/by-nc-nd/4.0/).

Thieme Medical and Scientific Publishers Pvt. Ltd. A-12, 2nd Floor, Sector 2, Noida-201301 UP, India 
high-density lipoprotein (HDL) (7.98\%), and cholesterol (9.76\%), but they were within respective TEa limits. Low-density lipoprotein (LDL) (-0.67\%), creatinine $(0.94 \%)$, albumin $(0.87 \%)$, total protein $(1.00 \%)$, ferritin $(-0.58 \%)$, and triglycerides (TAG) $(2.82 \%)$ concentrations remained stable following the freeze-thaw cycle. In conclusion, single freeze-thaw cycle of the biomarkers in serum/plasma samples after storage at $-70^{\circ} \mathrm{C}$ for 1 month had minimal effect on stability of the studied analytes, and the changes in concentration were within acceptable limit for all analytes.

\section{Introduction}

The stability of biological samples collected in large-scale field surveys is critical for accurate biochemical measurements. Following collection and transport to laboratories for processing, biological samples are analyzed immediately or frozen for a period of time and thawed prior to analysis. Freeze-thaw cycles have been shown to adversely affect the integrity of specimens, thereby reducing the reliability of biochemical measurements. However, most studies examining the effects of single/multiple freeze-thaw cycles have been conducted under laboratory conditions, with limited evidence from field survey settings. ${ }^{1-4}$

The 2016-2018 India Comprehensive National Nutrition Survey (CNNS) was conducted to assess the national prevalence of key micronutrient deficiencies, subclinical inflammation, and noncommunicable disease risk factors through the measurement of respective biomarkers among approximately 50,000 children and adolescents ranging from 0 to 19 years of age. ${ }^{5}$ Pre- and postanalytical variations arising due to differences in sample handling conditions may alter the properties of the analytes being measured. Although it is ideal to maintain the analytical conditions uniformly, this is not always feasible in large-scale surveys. Therefore, stability of biomarkers needs to be ensured across a variety of anticipated conditions encountered in field settings,

In this study, the stability of analytes such as ferritin, soluble transferrin receptor (sTfR), vitamin B12, vitamin D, C-reactive protein (CRP), total cholesterol, high-density lipoprotein (HDL), low-density lipoprotein (LDL), triglycerides (TAG), albumin, creatinine, and total protein in serum and plasma glucose was assessed, following a 1-month single freeze-thaw cycle, a condition commonly practiced in large-scale surveys.

\section{Methods}

\section{Sample Collection}

A total of 70 subjects who volunteered and consented to provide blood sample were recruited in the study, using a camp approach from the National Capital Territory, India, for studying all the analytes. The study was ethically approved by the ethics committee of the All India Institute of Medical Sciences (AIIMS), New Delhi, India.

\section{Study Protocol}

Venous blood samples were collected by trained phlebotomists from subjects after an overnight fast. Blood from subjects were collected in SST vacutainers (Becton Dickinson) for assessing stability of ferritin, vitamin B12, vitamin D, sTfR, total cholesterol, HDL, LDL, TAG, albumin, total protein, and creatinine; for glucose estimation, blood was collected in fluoride vacutainers (Becton Dickinson). Blood was immediately transferred to 2 to $8^{\circ} \mathrm{C}$ and centrifuged after 30 minutes at $1700 \times$ g for 10 minutes to separate serum/plasma, which was analyzed without delay to obtain the baseline value $\left(\mathrm{T}_{0}\right)$. Following the analysis, the sample was stored at $-70^{\circ} \mathrm{C}$ for 1 month after which the samples were taken out from the freezer and allowed to thaw at room temperature and then reanalyzed $\left(\mathrm{T}_{1}\right)$.

The methods and platforms/analyzer used to measure baseline and freeze-thaw concentrations for the 13 biochemical analytes examined in the study are presented in - Table 1.

\section{Statistical Analysis}

Serum/plasma samples were analyzed at baseline $\left(\mathrm{T}_{0}\right)$ (day of blood collection) and following a 1-month freeze-thaw cycle $\left(\mathrm{T}_{1}\right)$. Mean $\mathrm{T}_{0}$ and $\mathrm{T}_{1}$ concentrations were compared using paired sample $t$-tests, and differences were evaluated according to total allowable error (TEa) limits (desirable bias). The stability of analytes following the freeze-thaw cycle was assessed based on the mean percentage change from $\mathrm{T}_{0}$ to $\mathrm{T}_{1}$ values (bias).The least significant change (LSC) was calculated based on the coefficient of variation and was considered statistically significant if it exceeded the TEa for the respective analyte. ${ }^{6}$ The level of bias and corresponding limits of agreement were presented using Bland-Altman plots. Reported $p$ values are 2 -sided with $\alpha=0.05$. Statistical analyses were performed using SPSS Version 22.0 (IBM Inc.)

\section{Results}

The mean percentage difference between $\mathrm{T}_{0}$ and $\mathrm{T}_{1}$ concentrations (bias) was largest for vitamin $\mathrm{D}(-12.51 \%$; $95 \% \mathrm{CI}$ : 17.00, - 7.83), cholesterol (9.76\%; 95\% CI: 8.41, 11.10), and HDL (7.98\%; 95\% CI: 5.33, 10.84) and smallest for ferritin (-0.58\%; 95\% CI: $-3.44,2.29)$ and $\mathrm{LDL}(-0.67 \% ; 95 \% \mathrm{CI}:-2.16$, 1.48) (-Table 2). Mean differences for cholesterol, glucose, 
Table 1 Details of the biochemical analytes studied for stability in blood sample following exposures to different temperature and time conditions, their methodology for analysis, and the platforms/instruments used

\begin{tabular}{|c|c|c|}
\hline $\begin{array}{l}\text { Analyte studied/ } \\
\text { Sample type used }\end{array}$ & $\begin{array}{l}\text { Methodology used } \\
\text { for analysis }\end{array}$ & $\begin{array}{l}\text { Platforms used } \\
\text { in analysis }\end{array}$ \\
\hline $\begin{array}{l}\text { C-reactive protein } \\
\text { (Serum) }\end{array}$ & Immunoturbidimetric & $\begin{array}{l}\text { Beckman } \\
\text { Coulter, AU 480, } \\
\text { USA }\end{array}$ \\
\hline $\begin{array}{l}\text { Total protein } \\
\text { (serum) }\end{array}$ & $\begin{array}{l}\text { Spectrophotometric, } \\
\text { Biuret }\end{array}$ & $\begin{array}{l}\text { Beckman } \\
\text { Coulter, AU 680, } \\
\text { USA }\end{array}$ \\
\hline $\begin{array}{l}\text { Albumin } \\
\text { (serum) }\end{array}$ & $\begin{array}{l}\text { Spectrophotometric, } \\
\text { BCP dye binding }\end{array}$ & $\begin{array}{l}\text { Beckman } \\
\text { Coulter, AU 680, } \\
\text { USA }\end{array}$ \\
\hline $\begin{array}{l}\text { Ferritin } \\
\text { (serum) }\end{array}$ & $\begin{array}{l}\text { Chemiluminescence/ } \\
\text { two-site sandwich } \\
\text { immunoassay }\end{array}$ & $\begin{array}{l}\text { Advia Centaur } \\
\text { XP, Siemens, USA }\end{array}$ \\
\hline $\begin{array}{l}\text { Soluble transferrin } \\
\text { receptor (serum) }\end{array}$ & Immunoturbidimetric & $\begin{array}{l}\text { Beckman } \\
\text { Coulter, AU 480, } \\
\text { USA }\end{array}$ \\
\hline $\begin{array}{l}\text { Vitamin B12 } \\
\text { (serum) }\end{array}$ & $\begin{array}{l}\text { Chemiluminescence/ } \\
\text { two-site sandwich } \\
\text { immunoassay }\end{array}$ & $\begin{array}{l}\text { Advia Centaur } \\
\text { XP, Siemens, USA }\end{array}$ \\
\hline $\begin{array}{l}\text { Vitamin } 25(\mathrm{OH}) \mathrm{D} \\
\text { (serum) }\end{array}$ & $\begin{array}{l}\text { Chemiluminescence/ } \\
\text { two-site sandwich } \\
\text { immunoassay }\end{array}$ & $\begin{array}{l}\text { Advia Centaur } \\
\text { XP, Siemens, USA }\end{array}$ \\
\hline $\begin{array}{l}\text { Glucose } \\
\text { (plasma) }\end{array}$ & $\begin{array}{l}\text { Spectrophotometric, } \\
\text { hexokinase (UV) }\end{array}$ & $\begin{array}{l}\text { Beckman } \\
\text { Coulter, AU 680, } \\
\text { USA }\end{array}$ \\
\hline $\begin{array}{l}\text { Total cholesterol } \\
\text { (serum) }\end{array}$ & $\begin{array}{l}\text { Spectrophotometric, } \\
\text { cholesterol oxidase } \\
\text { esterase peroxidase }\end{array}$ & $\begin{array}{l}\text { Beckman } \\
\text { Coulter, AU 680, } \\
\text { USA }\end{array}$ \\
\hline $\begin{array}{l}\mathrm{HDL} \\
\text { (serum) }\end{array}$ & $\begin{array}{l}\text { Spectrophotometric, } \\
\text { direct measure-PEG/ } \\
\text { CHOD }\end{array}$ & $\begin{array}{l}\text { Beckman } \\
\text { Coulter, AU 680, } \\
\text { USA }\end{array}$ \\
\hline $\begin{array}{l}\mathrm{LDL} \\
\text { (serum) }\end{array}$ & $\begin{array}{l}\text { Spectrophotometric, } \\
\text { Direct Measure/ } \\
\text { CHOD }\end{array}$ & $\begin{array}{l}\text { Beckman } \\
\text { Coulter, AU 680, } \\
\text { USA }\end{array}$ \\
\hline $\begin{array}{l}\text { TAG } \\
\text { (serum) }\end{array}$ & $\begin{array}{l}\text { Spectrophotometric, } \\
\text { enzymatic endpoint }\end{array}$ & $\begin{array}{l}\text { Beckman } \\
\text { Coulter, AU 680, } \\
\text { USA }\end{array}$ \\
\hline $\begin{array}{l}\text { Creatinine } \\
\text { (serum) }\end{array}$ & $\begin{array}{l}\text { Spectrophotometric, } \\
\text { alkaline picrate } \\
\text { kinetic (Jaffe's } \\
\text { method) }\end{array}$ & $\begin{array}{l}\text { Beckman } \\
\text { Coulter, AU 680, } \\
\text { USA }\end{array}$ \\
\hline
\end{tabular}

Abbreviations: HDL, high-density lipoprotein; LDL, low-density lipoprotein; TAG, triglycerides.

HDL, CRP, vitamin B12 $(p=0.010)$, sTfR $(p=0.040)$, and vitamin D were statistically significant $(p=0.000)$. There were no significant differences between $\mathrm{T}_{0}$ and $\mathrm{T}_{1}$ concentrations for LDL, creatinine, albumin, total protein, TAG, and ferritin (-Table 2).

-Table 3 includes the coefficient of variation (CV), LSC and TEa for each bioanalytes. The calculated LSC was less than the respective TEa for all bioanalytes except for serum albumin.

The level of agreement between $\mathrm{T}_{0}$ and $\mathrm{T}_{1}$ concentrations was relatively consistent for glucose, ferritin, TAG, CRP, sTfR, and vitamin B12 in contrast to cholesterol (1a), LDL (1d),
HDL (1c), creatinine (1 g), albumin (1f), total protein (1h), and vitamin D (11), as can be seen in - Fig. 1.

\section{Discussion}

In this study, we examined the stability of 13 bioanalytes following a single one-month freeze-thaw cycle. A significant change in mean concentration from baseline was observed for cholesterol, glucose, HDL, CRP, sTfR, vitamin B12 and vitamin $\mathrm{D}$, although these differences were within TEa limits and therefore considered to be the reliable estimate of these analytes.

We observed more than $12 \%$ reduction in vitamin D concentrations following the single freeze-thaw cycle. The susceptibility of vitamin $D$ to freeze-thaw cycles has been shown in other studies. A $2.6 \%$ increase in vitamin D concentration after a single freeze-thaw cycle was reported by Wielders et al, ${ }^{7}$ using a chemiluminescence platform. Wielders et al have also reported a $4.0 \%$ decrease in the mean concentration following storage at $-20^{\circ} \mathrm{C}$ for up to 2 months. They also observed a mean decrease of $2.3,3.4$, and $8.5 \%$ after 72 hours, 24 hours, and 7 days storage of whole blood at room temperature, respectively; however, they were less than the analytical interassay precision. Enko et al studied a new generation of vitamin D assays and have reported a within-run and between-run imprecision of $\leq 20 \%$ at each of the evaluated concentration levels. ${ }^{8}$

Riley et $\mathrm{al}^{9}$ reported a maximum $11 \%$ bias for vitamin D levels across three freeze-thaw cycles, when compared with one freeze-thaw process. In contrast, Antonuicci et $\mathrm{al}^{10}$ reported the stability of vitamin $D$ in serum for up to four freeze-thaw cycles using a DiaSorin RIA assay. However, the study did not assess vitamin D levels prior to freezing, as samples were subjected to at least one freeze-thaw before analysis. Lewis et al $^{11}$ also showed the stability of vitamin D in serum during multiple freeze-thaw cycles and exposure to UV and sunlight for up to 8 days using high-performance liquid chromatography (HPLC) tandem mass spectrometry.

In our study, plasma glucose concentrations were approximately $2 \%$ higher after the single freeze-thaw, as compared with baseline concentrations. This is in contrast to a study by Clark et al who reported a significant decrease in glucose concentration following a single freeze-thaw cycle using the hexokinase method. ${ }^{12}$ Studies have examined the long-term stability of plasma glucose under multiple freeze-thaw exposures and have shown a temperature and time-dependent decrease in concentration. ${ }^{1,2,13}$ However, in a study by Flood et al, glucose concentrations was reported to show an increase from 11.8 to $14.0 \%$ in human serum refrozen and thawed even once. ${ }^{3}$ The values were within the TEa.

We observed approximately $10 \%$ and approximately $8 \%$ increase in freeze-thaw concentrations of cholesterol and HDL, respectively, compared with concentrations in fresh (baseline) samples. There is variable evidence on the effects of freeze-thaw cycles on cholesterol and HDL. Ugwuezumba et al reported a nonsignificant reduction in cholesterol and HDL in serum samples, following a freeze-thaw using the enzymatic colorimetric method. ${ }^{14}$ 
The Effects of a Single Freeze-Thaw Cycle on Concentrations of Biomarkers Abraham et al.

Table 2 Mean baseline and 30-day freeze-thaw concentrations and percentage change from baseline for the biochemical analyte

\begin{tabular}{|l|l|l|l|l|l|}
\hline Analyte & $\mathrm{N}$ & $\begin{array}{l}\text { Mean baseline } \\
\text { concentration }\left(\mathrm{T}_{0}\right)\end{array}$ & $\begin{array}{l}\text { Mean freeze-thaw } \\
\text { concentration }\left(\mathrm{T}_{1}\right)\end{array}$ & $\begin{array}{l}\text { Mean \% difference } \\
(95 \% \mathrm{Cl})\end{array}$ & $p$-Value \\
\hline Cholesterol $(\mathrm{mg} / \mathrm{dL})$ & 70 & $167.09 \pm 38.34$ & $183.76 \pm 44.52$ & $9.76(8.41,11.10)$ & 0.000 \\
\hline LDL $(\mathrm{mg} / \mathrm{dL})$ & 67 & $111.28 \pm 33.54$ & $110.8 \pm 33.54$ & $-0.67(-2.16,1.48)$ & 0.619 \\
\hline Glucose $(\mathrm{mg} / \mathrm{dL})$ & 68 & $118.79 \pm 61.47$ & $121.02 \pm 62.09$ & $1.93(1.49,2.38)$ & 0.000 \\
\hline HDL $(\mathrm{mg} / \mathrm{dL})$ & 69 & $40.51 \pm 7.5$ & $43.47 \pm 7.86$ & $7.98(5.33,10.84)$ & 0.000 \\
\hline Serum creatinine $(\mathrm{mg} / \mathrm{dL})$ & 69 & $0.62 \pm 0.15$ & $0.61 \pm 0.16$ & $0.94(-2.09,3.97)$ & 0.250 \\
\hline Serum albumin $(\mathrm{mg} / \mathrm{dL})$ & 70 & $4.42 \pm 0.31$ & $4.46 \pm 0.42$ & $0.87(-0.55,2.29)$ & 0.210 \\
\hline Total protein $(\mathrm{g} / \mathrm{dL})$ & 70 & $7.85 \pm 0.48$ & $7.92 \pm 0.60$ & $1.00(-0.34,2.34)$ & 0.152 \\
\hline Ferritin $(\mathrm{ng} / \mathrm{mL})$ & 61 & $77.52 \pm 71.10$ & $78.66 \pm 75.74$ & $-0.58(-3.44,2.29)$ & 0.413 \\
\hline TAG $(\mathrm{mg} / \mathrm{dL})$ & 70 & $171.76 \pm 138.42$ & $173.97 \pm 120.46$ & $2.82(1.16,4.49)$ & 0.458 \\
\hline CRP $(\mathrm{mg} / \mathrm{dL})$ & 67 & $3.97 \pm 5.77$ & $4.12 \pm 5.99$ & $3.45(1.90,5.00)$ & 0.000 \\
\hline Vitamin B12 $(\mathrm{pg} / \mathrm{mL})$ & 56 & $254.50 \pm 103.61$ & $242.75 \pm 103.61$ & $-3.74(-6.81,-3.37)$ & 0.010 \\
\hline sTfR & 70 & $29.13 \pm 39.38$ & $27.66 \pm 35.05$ & $-5.49(-7.61,23.48)$ & 0.040 \\
\hline Vitamin D $(\mathrm{ng} / \mathrm{mL})$ & 60 & $12.98 \pm 8.27$ & $10.53 \pm 4.96$ & $-12.51(-17.0,-7.83)$ & 0.000 \\
\hline
\end{tabular}

Abbreviations: CRP, C-reactive protein; HDL, high-density lipoprotein; LDL, low-density lipoprotein; TAG, triglycerides.

Note: All concentrations are mean \pm SD. Percentage differences were calculated using paired sample $t$-tests. $p<0.05$.

Table 3 Coefficient of variation, least significant change, and total allowable error values for study analytes

\begin{tabular}{|l|l|l|l|}
\hline Analyte & CV (\%) & LSC (\%) & TEa (\%) \\
\hline Glucose (mg/dL) & 1.84 & 3.75 & 5.50 \\
\hline Cholesterol (mg/dL) & 4.22 & 5.69 & 9.01 \\
\hline LDL $(\mathrm{mg} / \mathrm{dL})$ & 3.49 & 5.17 & 11.90 \\
\hline HDL $(\mathrm{mg} / \mathrm{dL})$ & 3.70 & 5.32 & 11.63 \\
\hline Serum creatinine (mg/dL) & 1.82 & 3.73 & 8.87 \\
\hline Serum albumin $(\mathrm{g} / \mathrm{dL})$ & 2.30 & 4.20 & 4.07 \\
\hline Total protein $(\mathrm{g} / \mathrm{dL})$ & 0.98 & 2.74 & 3.63 \\
\hline Ferritin $(\mathrm{ng} / \mathrm{mL})$ & 8.92 & 8.92 & 16.90 \\
\hline TAG $(\mathrm{mg} / \mathrm{dL})$ & 3.47 & 5.15 & 25.99 \\
\hline CRP $(\mathrm{mg} / \mathrm{dL})$ & 2.60 & 4.46 & 56.60 \\
\hline Vitamin B12 $(\mathrm{pg} / \mathrm{mL})$ & 8.79 & 8.25 & 30.00 \\
\hline sTfR & 3.00 & 4.79 & NA \\
\hline Vitamin D $(\mathrm{ng} / \mathrm{mL})$ & 4.76 & 6.04 & 17.01 \\
\hline
\end{tabular}

Abbreviations: CRP, C-reactive protein; CV, coefficient of variation; HDL, high-density lipoprotein; LDL, low-density lipoprotein; LSC, least significant change; NA, not available; TEa, total allowable error; TAG, triglycerides.

Another freeze-thaw study using rat serum demonstrated no change in cholesterol and a $2 \%$ increase in HDL concentrations following a 24-hour freeze-thaw. ${ }^{4}$ Similar effects $(<3 \%$ increase) have been observed for HDL concentrations using the heparin manganese procedure and enzymatic methods. ${ }^{15}$ Ignatius et al demonstrated a nonsignificant change in concentration of cholesterol $(+1.5 \%)$ and HDL $(-2.9 \%)$ after a 2-day freeze-thaw using the enzymatic-spectrophotometric method and precipitation/enzymatic-spectrophotometric method, respectively. ${ }^{16}$

In our study, freeze-thaw concentrations of CRP were approximately 5.5\% higher compared with prefreeze baseline concentrations. This is in contrast to studies that have shown CRP to be stable across multiple freeze-thaw cycles. A study by Doumatey et $\mathrm{al}^{17}$ that used the latex particle-enhanced immunoturbidimetric assay revealed CRP may be stable in serum for an average period of 8.7 years. Ajij et $\mathrm{al}^{18}$ showed CRP to be stable in serum for up to seven freeze-thaw cycles using the sandwich enzyme immunoassay. In addition, Macy et $\mathrm{al}^{19}$ observed stable CRP concentrations in serum for up to four freeze-thaw cycles. The increase in CRP observed in our study was well within the TEa limits.

We observed a significant $3.7 \%$ decrease in vitamin B12 concentration after one freeze-thaw cycle. Although there is some evidence to support this, ${ }^{20}$ most studies suggest vitamin B12 is stable when exposed to freeze-thaw cycles. Jee et $\mathrm{al}^{21}$ showed a notable decrease in vitamin B12 concentration only after three freeze-thaw cycles for serum stored at $-20^{\circ} \mathrm{C}$ for 2 to 10 months and analyzed using the Siemens Immulite 2000u. A study by Gislefoss et a ${ }^{22}$ that investigated the effects of multiple freeze-thaw $(1,2,3,5$, and 10) cycles on serum stored at $-25^{\circ} \mathrm{C}$ using the modular E170 




(c) HDL

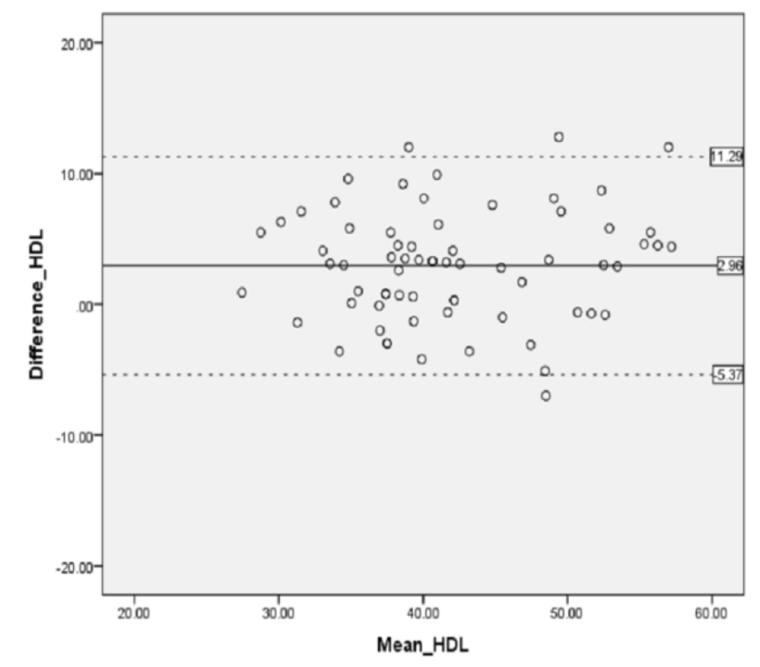

(e) TAG

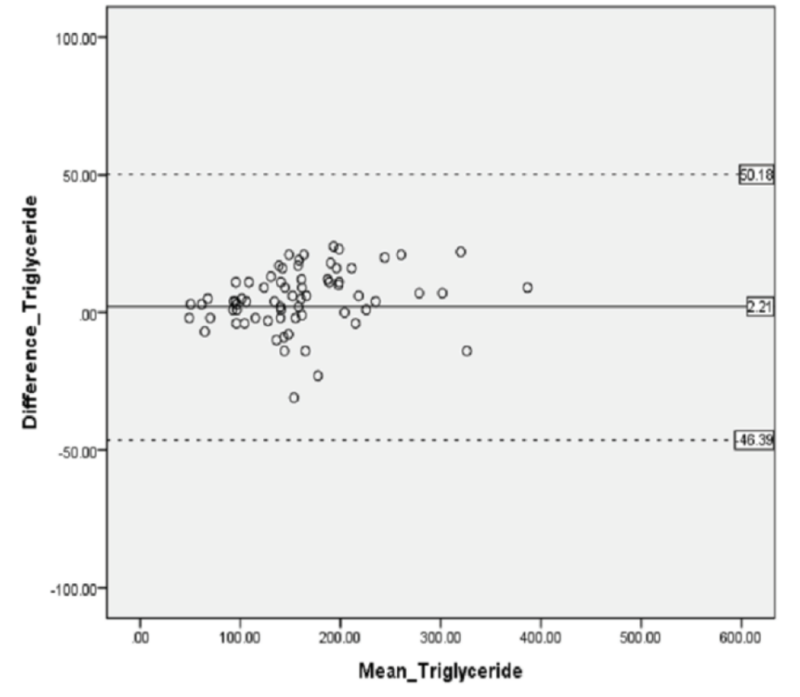

(b) Glucose

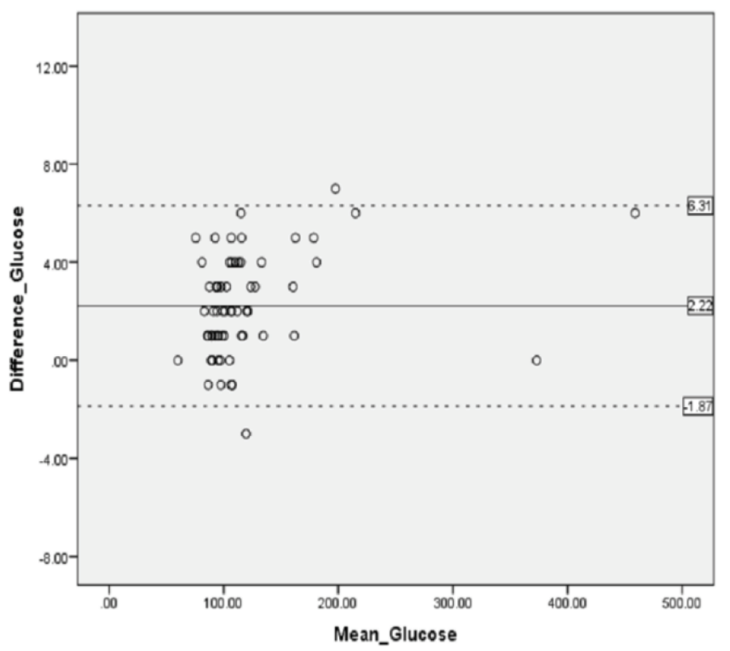

(d) LDL

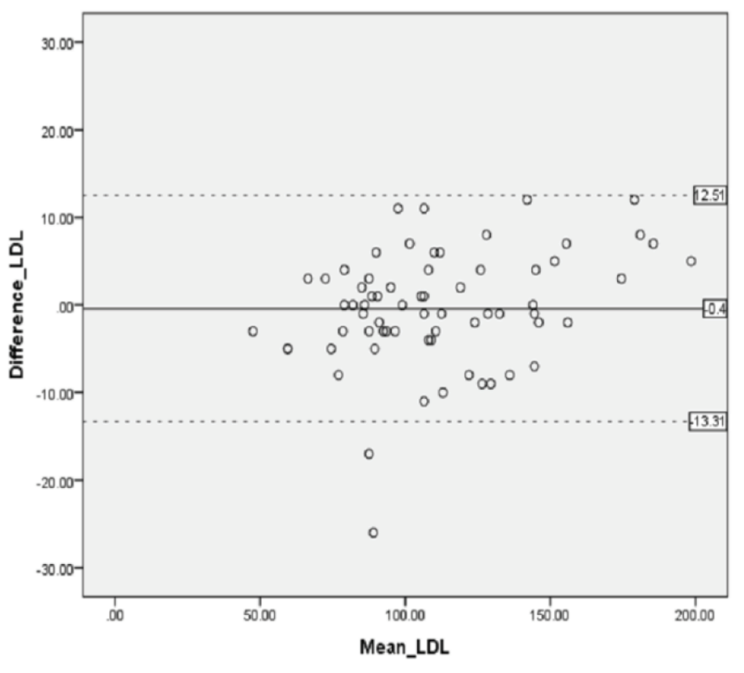

(f) Albumin

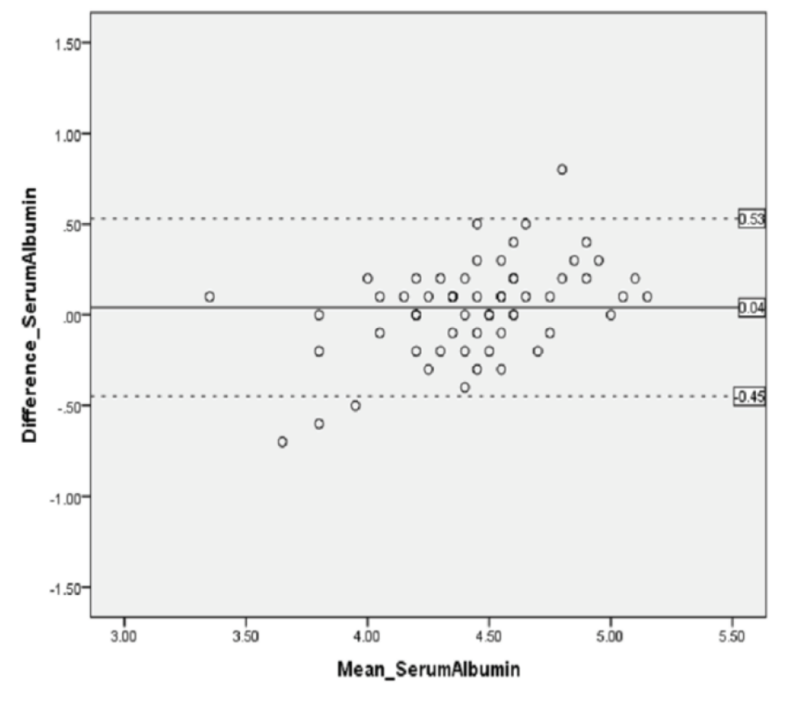




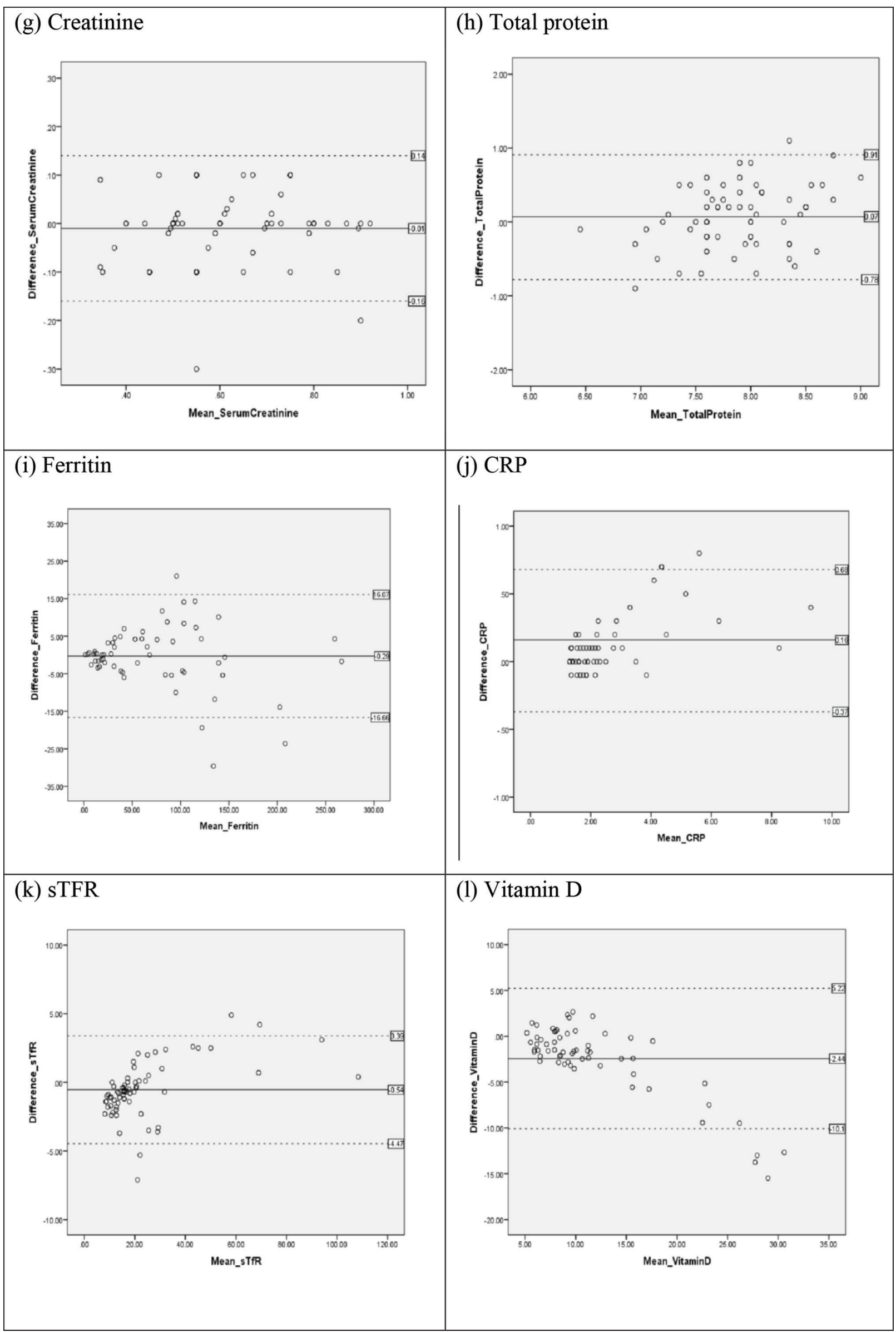




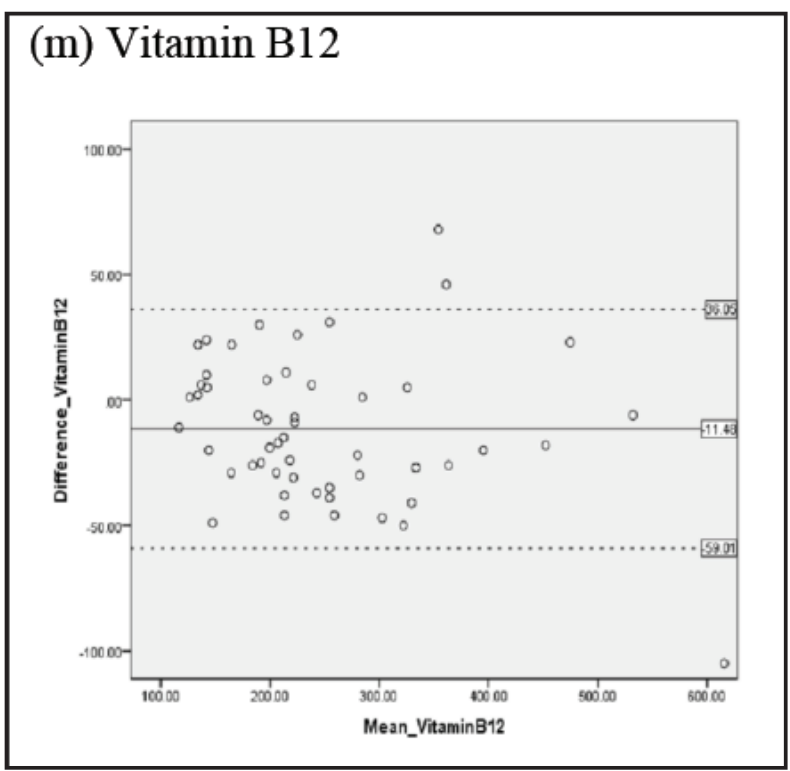

Fig. 1 Bland-Altman plots for study analytes. (a-m) Bland-Altman plots for biochemical analytes with the mean of two measurements, at baseline and after freeze thaw cycle, for each subject on X-axis and difference in two measurements on Y-axis. In each figure, the horizontal lines above and below the mean indicate the two SD limits.

(Roche) electrochemiluminescence immunoassay showed a nonsignificant change between vitamin B12 concentrations in fresh versus single freeze-thaw samples and between concentrations in samples exposed to one versus multiple freeze-thaw cycles.

For sTfR, the mean $\mathrm{T}_{1}$ concentration was significantly lower $(5.5 \%)$ than the baseline concentration. Pfeiffer et $\mathrm{al}^{23}$ reported a nonsignificant decrease $(<1 \%)$ in sTfR concentration after one freeze-thaw cycle, when compared with samples stored at $-70^{\circ} \mathrm{C}$, and observed a nonsignificant decrease of $2 \%$ in sTfR concentrations following subsequent freeze-thaw cycles.

There was no significant change in mean concentration after the freeze-thaw cycle for LDL, serum creatinine, serum albumin, total protein, ferritin, and TAG. Kachwaa et al in a similar study where serum was stored at $-20^{\circ} \mathrm{C}$ for 30 days have reported stability for creatinine, total protein, albumin, cholesterol, and TAG levels. ${ }^{24}$ Albumin, cholesterol, creatinine, C-reactive protein, glucose, TAG, and vitamin B12 were seen to be robust among the studied analytes for up to 10 repeated thaw cycles compared with baseline level in the study conducted by Gislefoss et al. ${ }^{22}$

With the exception of serum albumin, all LSC concentrations were within acceptable TEa limits. The observed changes in freeze-thaw concentrations may be due to the leakage from blood cells, exchange of serum and erythrocyte content, serum clot formation, increased hematocrit, degradation of proteins, differential storage conditions and methods of assessment.

It is important to distinguish our results from studies comparing the stability of analytes exposed to single versus multiple freeze-thaw cycles, as our values are based on comparisons between single freeze-thaw and fresh samples (prior to freezing). As Kronenberg25 notes, differences have shown to be greater after the first freeze-thaw cycle and thus may explain the larger differences in analyte concentrations observed in our study. Our findings suggest a single 1-month freeze-thaw cycle has no meaningful effect on serum and plasma concentrations of key micronutrient, noncommunicable disease (NCD), and inflammatory biomarkers. Further evidence is needed on the stability of analytes undergoing freeze-thaw processes compared with fresh samples.

\section{Authors Contribution}

All authors contributed to the study conception and design. Material preparation, data collection and analysis were performed by Ransi Ann Abraham, Garima Rana and the Population Council team. The first draft of the manuscript was written by Ransi Ann Abraham, and all authors commented on the previous versions of the manuscript. All authors read and approved the final manuscript.

\section{Conflicts of Interest}

The authors declare that they have no conflicts of interest. The views expressed are those of the authors and do not necessarily reflect those of their organization.

\section{Acknowledgments}

The project was funded by Aditya Mittal, President of ArcelorMittal, and Megha Mittal, Managing Director of ESCADA.

\section{Reference}

1 Cuhadar S, Koseoglu M, Atay A, Dirican A. The effect of storage time and freeze-thaw cycles on the stability of serum samples. Biochem Med (Zagreb) 2013;23(1):70-77

2 Tanner M, Kent N, Smith B, Fletcher S, Lewer M. Stability of common biochemical analytes in serum gel tubes subjected to various storage temperatures and times pre-centrifugation. Ann Clin Biochem 2008;45(Pt 4):375-379 
3 Flood A, Pfeiffer R, Mai V, Remaley A, Lanza E, Schatzkin A. \# 103 The effects of freeze-thaw cycles on serum measurement of insulin and glucose in epidemiologic studies. Ann Epidemiol 2002;12(7):528

4 Kale VP, Patel SG, Gunjal PS, et al. Effect of repeated freezing and thawing on 18 clinical chemistry analytes in rat serum. J Am Assoc Lab Anim Sci 2012;51(4):475-478

5 Ministry of Health and Family Welfare (MoHFW), Government of India, UNICEF and Population Council. Comprehensive National Nutrition Survey (CNNS) National Report. New Delhi: MoHFW; 2019

6 Ricos C, Alvarez V, Cava F, Garcia-Lario JV, Hernandez A, Jimenez CV, Minchinela J, Perich C, Simon M. Current databases on biologic variation: pros, cons and progress. Scand J Clin Lab Invest 1999;59:491-500. Updated 2014

7 Wielders JP, Wijnberg FA. Preanalytical stability of 25(OH)vitamin D3 in human blood or serum at room temperature: solid as a rock. Clin Chem 2009;55(8):1584-1585

8 Enko D, Kriegshäuser G, Stolba R, Worf E, Halwachs-Baumann G. Method evaluation study of a new generation of vitamin D assays. Biochem Med (Zagreb) 2015;25(2):203-212

9 Riley D. Method Development and Validation of Vitamin D2 and Vitamin D3 Using Mass Spectrometry [dissertation]. University of Washington, Seattle, WA; 2016

10 Antoniucci DM, Black DM, Sellmeyer DE. Serum 25-hydroxyvitamin D is unaffected by multiple freeze-thaw cycles. Clin Chem 2005;51(1):258-261

11 Lewis JG, Elder PA. Serum 25-OH vitamin D2 and D3 are stable under exaggerated conditions. Clin Chem 2008; 54(11):1931-1932

12 Clark ML, Humphreys SM, Frayn KN. Stability of plasma glucose during storage. Ann Clin Biochem 1990;27(Pt 4):373-377

13 Zhang DJ, Elswick RK, Miller WG, Bailey JL. Effect of serumclot contact time on clinical chemistry laboratory results. Clin Chem 1998;44(6 Pt 1):1325-1333

14 Ugwuezumba PC, Nwankpa P, Emengaha FC, Ekweogu CN, Etteh CC, Chukwuemeka OG. Influence of Freeze-Thawing and Storage on Human Serum Lipid Analytes. Int J Curr Microbiol Appl Sci 2018;7(10):3287-3294

15 Curb JD, Overturf ML, Harrist RB. Lability of HDL-cholesterol during serum storage. Atherosclerosis 1980;37(4):641-645
16 Ignatius CM, Emeka EN, Ebele JI, Chinelo VM, Fidelis EE, Silas AU. The effect of sample storage on total cholesterol and Hdl-cholesterol assays. Current Research Journal of Biological Sciences 2009;1(2):1-5

17 Doumatey AP, Zhou J, Adeyemo A, Rotimi C. High sensitivity C-reactive protein (Hs-CRP) remains highly stable in long-term archived human serum. Clin Biochem 2014;47(4-5):315-318

18 Aziz N, Fahey JL, Detels R, Butch AW. Analytical performance of a highly sensitive C-reactive protein-based immunoassay and the effects of laboratory variables on levels of protein in blood. Clin Diagn Lab Immunol 2003;10(4):652-657

19 Macy EM, Hayes TE, Tracy RP. Variability in the measurement of C-reactive protein in healthy subjects: implications for reference intervals and epidemiological applications. Clin Chem 1997;43(1):52-58

20 Jansen EHJM, Beekhof PK. Stability of folate and vitamin B12in human serum after long-term storage: a follow-up after 13 years. J Nutr Metab 2018;2018:9834181

21 Jee P, Fernandez L, Perkins SL, Brooks SP. Effect of storage and repeated freeze/thaw on (S) vitamin B12. Clin Biochem 2014;47(18):344

22 Gislefoss RE, Lauritzen M, Langseth H, Mørkrid L. Effect of multiple freeze-thaw cycles on selected biochemical serum components. Clin Chem Lab Med 2017;55(7):967-973

23 Pfeiffer CM, Cook JD, Mei Z, Cogswell ME, Looker AC, Lacher DA. Evaluation of an automated soluble transferrin receptor (sTfR) assay on the Roche Hitachi analyzer and its comparison to two ELISA assays. Clin Chim Acta 2007;382(1-2):112-116

24 Kachhawa K, Kachhawa P, Varma M, Behera R, Agrawal D, Kumar S. Study of the stability of various biochemical analytes in samples stored at different predefined storage conditions at an accredited laboratory of India. J Lab Physicians 2017;9(1):11-15

25 Kronenberg F, Lobentanz EM, König P, Utermann G, Dieplinger $\mathrm{H}$. Effect of sample storage on the measurement of lipoprotein[a], apolipoproteins B and A-IV, total and high density lipoprotein cholesterol and triglycerides. J Lipid Res 1994;35(7):1318-1328 